\title{
ADAMTS9 wt Allele
}

National Cancer Institute

\section{Source}

National Cancer Institute. ADAMTS9 wt Allele. NCI Thesaurus. Code C49725.

Human ADAMTS9 wild-type allele is located within 3p14.3-p14.2 and is approximately

$172 \mathrm{~kb}$ in length. This allele, which encodes ADAMTS-9, is involved in the proteolytic cleavage of large aggregating proteoglycans. 